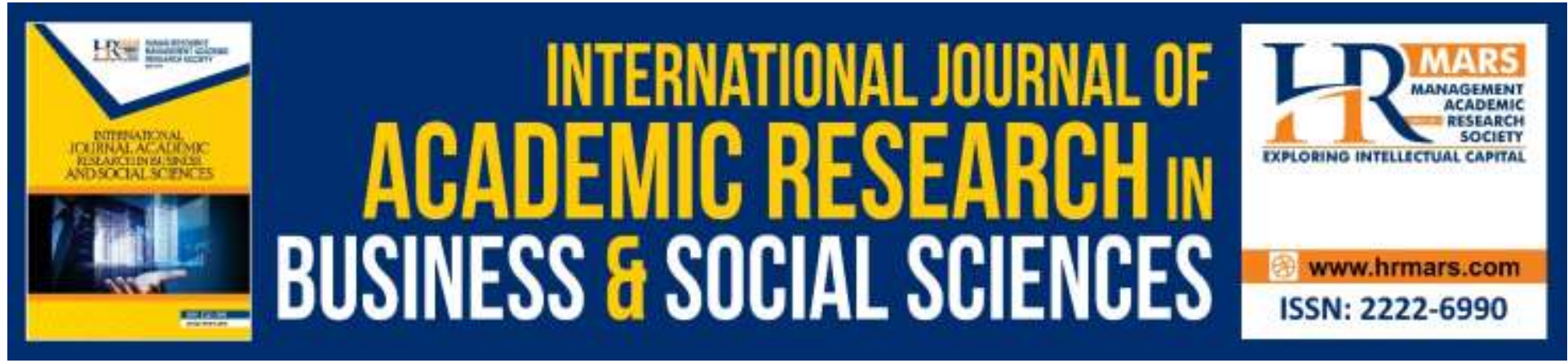

\title{
The Evaluation of Sulaymaniyah's Creative Sectors and the Capacity of the City to Become a Creative City
}

\author{
Dunya Muhammed, Osman Durmaz
}

To Link this Article: http://dx.doi.org/10.6007/IJARBSS/v9-i8/6231

DOI: $10.6007 /$ IJARBSS/v9-i8/6231

Received: 10 May 2019, Revised: 16 June 2019, Accepted: 27 July 2019

Published Online: 09 August 2019

In-Text Citation: (Muhammed \& Durmaz, 2019)

To Cite this Article: Muhammed, D., \& Durmaz, O. (2019). The Evaluation of Sulaymaniyah's Creative Sectors and the Capacity of the City to Become a Creative City. International Journal of Academic Research in Business and Social Sciences, 9(8), 152-162.

\section{Copyright: (C) 2019 The Author(s)}

Published by Human Resource Management Academic Research Society (www.hrmars.com)

This article is published under the Creative Commons Attribution (CC BY 4.0) license. Anyone may reproduce, distribute, translate and create derivative works of this article (for both commercial and non-commercial purposes), subject to full attribution to the original publication and authors. The full terms of this license may be seen at: http://creativecommons.org/licences/by/4.0/legalcode

\section{Vol. 9, No. 8, 2019, Pg. 152 - 162}

Full Terms \& Conditions of access and use can be found at http://hrmars.com/index.php/pages/detail/publication-ethics 


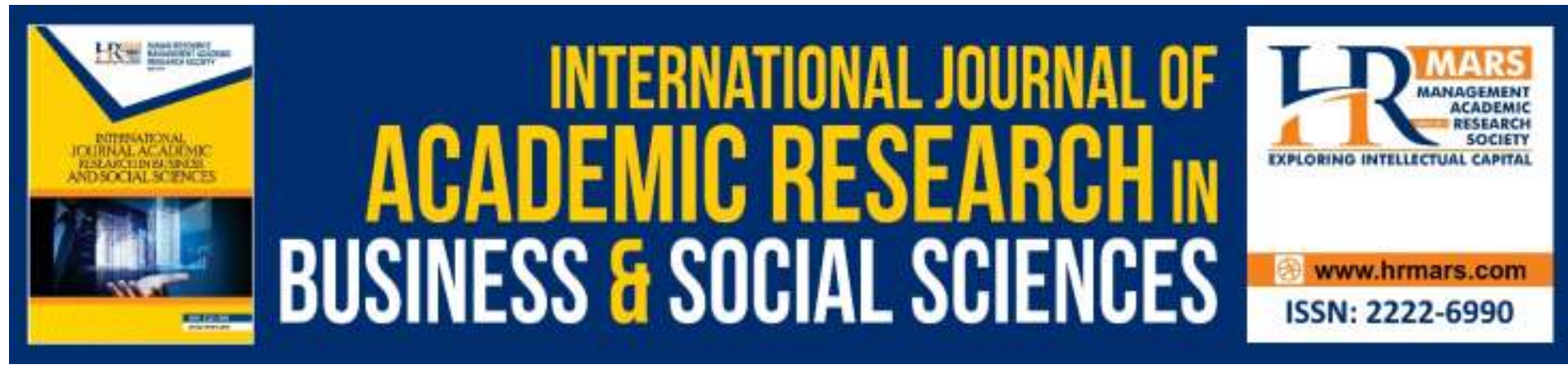

\title{
The Evaluation of Sulaymaniyah's Creative Sectors and the Capacity of the City to Become a Creative City
}

\author{
Dunya Muhammed, Osman Durmaz \\ Ishik University, Sulaimani, Kurdistan Region of Iraq \\ Email: duneamuhammad@gmail.com,osman.durmaz@ishik.edu.iq
}

\begin{abstract}
Sulaimaniyah as the capital city of culture depend on oil revenue for its economy. Oil is not sustainable, and it will cease to exist after 50 years according to many researches done. This research argues that sulaimaniyah has the capacity of becoming a creative city, but political issues and functionality of the city prevents cultural improvement and this issue negatively effects the creative economy. In sulaimaniyah there are many successful creative businesses that help the economy of the city and that opens the markets in their field of work. This research has been done to prove that sulaimaniyah has conflict in creative sectors but with a master plan, the city can fix its current economic problems by focusing on creative sectors and by building new cultural projects in the city rather than the focusing on the government to boost its economy.
\end{abstract}

Keywords: Creative City, Creativity, Economics, Creative City Capacity, Sulaymaniyah

\section{Introduction}

Creative city is a popularized concept that has been developed by Charles Landry* in the late 1980 s, it vitalizes the culture of creativity in urban planning and solutions to urban issues in every aspect. It gives support to new planning paradigm for cities to develop economically and socially.

The Creative city concept is a global movement that inspires artistic, social and cultural life of the cities to progress in its significance. historically, creativity has always been the moving force for cities to work as markets, trading and production centres, artists, students, administrators, power-brokers and entrepreneurs.

Creativity is a way of thinking to get away from rigid preconceptions and to open oneself to complex phenomena which cannot be dealt with strictly logical manner. Creativity changes concepts and perceptions. It helps human beings to be open to new ideas, influences and resources in order to create a richer and more sustainable environment.

Although, creativity is defined in many different ways by several authors. It is not strictly narrowed with some specific sentences. It is a wide subject that can be discussed in many ways. 
Meanwhile, many cities are lacking creativity in the world and they face difficulties of transition. Old industries are being neglected. The application of new knowledge to services, processes and products, is more considered in value-added than 'what' is being manufactured. This results in losing the cities' cultural identity.

This research focuses on sulaimaniyah city to become a creative city in order to increase and fix its economic issues. Sulaimaniyah is facing a significant downfall in terms of economics. Thus, by using creativity in thinking and by giving importance to the creative sectors it can build new economic strategies.

Sulaimaniyah city was built in 1784. It was the first Kurdish city that had an autonomous governing body, ruled by Kurdish leaders. Throughout the years, Sulaimaniyah developed into a cultural and political city after World War I. The Parliament of Kurdistan-Iraq announced Sulaimaniyah as the capital of culture on December $3^{\text {rd }}, 2012$. And as time passed by it grew to maintain a symbolic identity of a cultural city.

Sulaimaniyah could not fulfil the decision of becoming a cultural city, without a master plan. Consequently, it has neglected the areas with rich heritage and traditional buildings for their functionality. Such as; destroying old buildings and transforming them into car parking space shown in the (figure A) below or constructing skyscrapers over unique symbolic heritage sites.

Regardless of everything, the city still has many successful business owners that work on the creative sectors. Such as; Hama Group, H\&L Designs, Indigo Advertising Company, Maad Center, House of Kashma, Media Art Company, Culture Factory, etc. Also Sulaimaniyah has cultural, social, and symbolic capital. The history and structure of the city proves the cultural symbol of the city.

There are two main negative factors that affect Sulaymaniyah's cultural capital and creative sectors. Such as; the functionality of the city and the economic dependency on oil revenue. A functional city is a city that divides the city's land according to people's socio-economic situation. It prevents communication in the city and increases consumption of cars, destroys nature of the city for buildings, energy, etc. And for the researches that have been made about oil production they prove that oil will cease to exist in 50 years.

The purpose of this research is to evaluate the capacity of Sulaimaniyah to become a creative city with the intention of developing its economy, culture and sustainability. It supports the idea of creative economy. More importantly, the focus on this paper is to discover the potential that this city has where has not be taken into consideration. This research focused on the amount of companies that exist in Sulaimaniyah, by receiving data from Chamber of the amount of the companies from the creative sectors are calculated. Creative sector companies include: film production, music, printing, arts, crafting, radio stations, theatre, design, architecture, magazine, journalism, marketing and advertising, media and IT. Several creative companies or business owners were interviewed. The interviews included the following questions such as the performance of the company, for how many years they do this business, how much they offer employment opportunities or how many staff they have, did their capital increased or decreased, what is the quality of their business and how did they get successful. 
Another approach to clarify the subject for Sulaymaniyah's case was to get Sherwan Ali Hama Khan (Lecturer in Sulaimaniyah University) 's observation and research into consideration for this research's topic. He is the first researcher in sulaimaniyah that worked on the transformation of heritage places in the city to cultural centres.

This research has struggled to find data for analysing creative industries in sulaimaniyah. But, it is a positive factor that we obtained the number of companies or the perception of the creative business owners even if it isn't highly reliable. There is a huge research gap about this topic and sulaimaniyah city's governor's neglected culture and creativity in economic decisions.

\section{Literature Review}

\section{Importance of Arts and Culture and its Economic Effects}

Max weber (1864-1920), defines art in a sociological form. The systematic approach of logic and skill influencing the expected outcome, and also it is an application of knowledge and skill required to get developed production maintaining and as stated by aesthetic principles. (Omuaru \& Nyah, 2015)

To define economics, Encarta (2001) explains about economics as a management of resources to undertake the excessive expenditures or waste. Financial affairs, and it is the production, consumption of goods and services of a particular section of human beings. (Omuaru \& Nyah, 2015)

Arts and cultural industries add to economics. Since for a painting to be painted, there is requirement for the tools such as; canvases and paints. For a music to be recorded, there is a studio. For a film to be recorded, there is requirement for a camera and actress/actors. Etc., To sum up, the arts and cultural industry has a certain impact on economics. It adds and it contributes to macro and microeconomics.

To define Arts and culture industry, it is made clear that there is a wide various section in this industry. As mentioned in the introduction, different skills and creative works get into this industry.

\section{Developed and Developing Countries in Terms of Creative Sectors}

In the report of 'Contribution of the arts and culture industry to the UK economy' it is identified that a 'business economy' section of the arts and culture industry exists. This industry directly contributes the economics of UK. (Cebr, 2017)

It is found that Book publishing, performing arts and artistic inventions and creations have generated $£ 15.8$ billion income in 2015 directly to UK economics. This category of arts and culture industry have contributed and increase of 9.5 per cent since 2013 . Which is only 33 , 24 and 20 percent of the whole industry. (Cebr, 2017)

Arts and culture industry also have $f 20$ billion gross production in 2015 in UK. Also, an amount of 131,200 people has been employed to arts and culture industry. In the same year, England has approximately employed 119,000 people to this industry. Performing arts has been the largest contributor to UK's employment rate in economics. 35 per cent of total employment has been added by arts and culture industry. (Cebr, November 2017)

As many factors in the UK economics, the arts and culture are an effective industry on for the country. The purpose of this report is to present the amounts of arts and culture industry that 
adds to UK's economics. Also, Cebr has provided several reports for this subject in UK. (Cebr, November 2017)

This report is provided to analyse how the arts and culture industry contributes and adds to the four nations and nine English regions of UK and it also states about the impacts of this industry to economics. (Cebr, November 2017)

\section{Role of Creativity in Education, Psychology and Economy}

(Omuaru \& Nyah, 2015) during early 2000 creative arts has been compulsory and people that had limited knowledge of the arts were dissatisfied and they disagreed their children to study arts in school. While the ones that has enough knowledge of arts strongly resisted that there are things people don't learn by studying other subjects. It has always been argued that arts are a necessary subject for children to learn while they learn their mother language.

Education has always been a major factor in raising a child. American legislative actions made arts subject compulsory for every American child. This action made the economy of America a supremacy before Asian markets raised up. America has been the center of the world's economy and the reason for that was the action that has been made about arts subject vision. (Omuaru \& Nyah, 2015)

Achebe (1986) points out that "the arts are not the poor relation of the economy of the world, and on the contrary, they are the source of its vitality." (Omuaru \& Nyah, 2015)

\section{Creative City}

The urban policies that are filled with intellectual dominancy, is significantly shaped from the belief of importance of (instrumental, rational and analytical) thinking. (Landry, 2012) Despite having many positive sides including the turnover of cities from the most brutal and sick places to the most life supporting urban areas, despite all the systems that it has provided to the cities, yet it is not free of limits. It categorizes understanding and literacy into different frames, forcing orders over nature.

"What we describe as creative thinking is a way of getting rid of rigid of preconceptions and of opening ourselves to complex phenomena which cannot always be dealt with in a strictly logical manner. It is also a way of discovering previously unseen possibilities, everybody is potentially creative but organizational structures, habits of mind and working practices can squeeze creativity out." Says (Landry, 2012) in The creative cities.

So creative city is a city in which activities and governance of joints are accompanied with creativity instead of strict rules of instruments and tools.

Basically, cities ruled by instruments and tools, are not complete in terms of governance. The deeper the uses and utilizations are by means of instruments and tools, the less creative the community/city becomes.

Then comes the idea of a creative city in terms of economy. When a city's economy is highly influenced by classic tool and instrument sales and uses, that city is not categorized by creativity.

However, when most of a city's income depends on creative sectors such as; music, arts, film production, publishing, computer service, radio, graphics, advertisement, museums, library, crafts, architecture, and performing, etc. The city becomes a creative city in economy.

A proposal paper has been published in Sulaimanyah regarding the Cigarettes factory to transform into a cultural factory. The place has been a factory and an industrial area serving as a very significant place in the city's economy. The place has become part of the city's 
culture thr propose wants to maintain the area and use it as a cultural place instead of tearing it down and building skyscrapers instead. "when the city starts to become a creative city, local tourists start forming. The people of the city relive the cultural activities" says (khan, 2019) Sulaimaniyah must own the name it has. An ancient place like cigarettes factory like (khan, 2019) claims, should become a place for culture and activities related to arts and creative sectors. So that hopefully the city relieves he capacity that it has.

\section{Art and Culture Bring a Massive Economic Prosperity}

Based on the reports of (Arts \& Economic prosperity 5) shows the contribution of arts and culture industries in Billions of dollars from 2008 to 2014 as shown below:

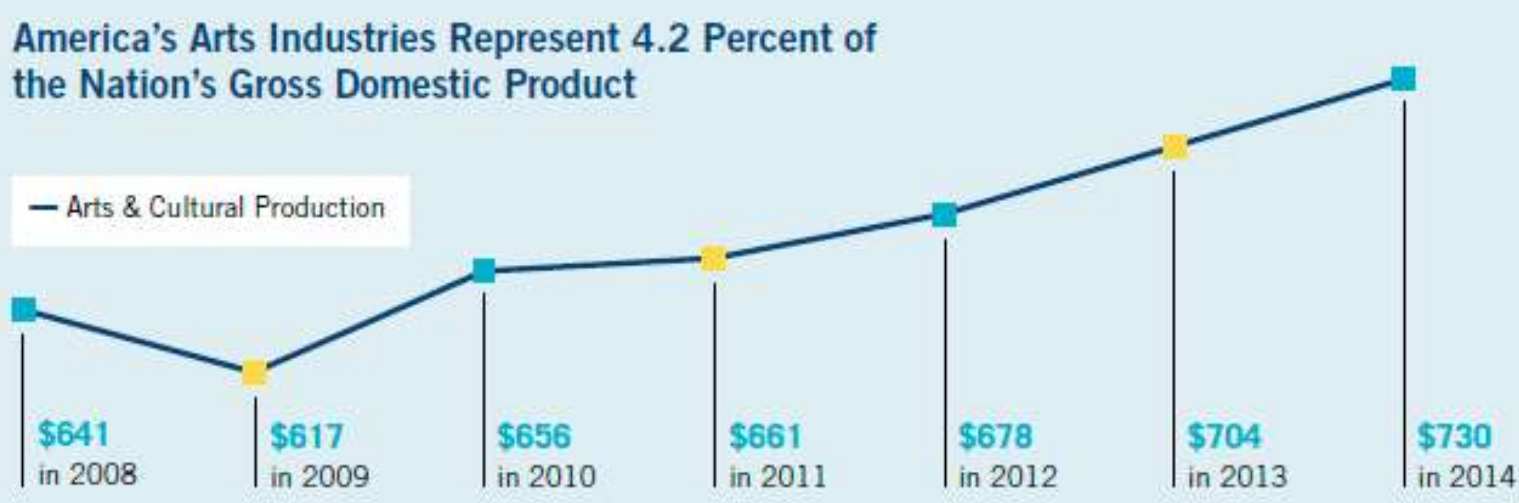

Contributions to the GDP by Arts \& Culture Industries (Billions of Dollars)

Just like what is mentioned in the America's Arts industries reports, the ratio is very significant to be considered in anywhere else in the globe. In our country as well, the dependency of the citites especially sulaimani is horrific and will lead to future damages in economy if not suspended and transformed into other Art related sectors.

The USA has been ruling the world lately and the main reason is that they consider arts as an important subject for kids to study. Iraqi economy or (Kurdistan regional government) KRG's economy is not stable due to its mere dependency on oil. Manufacturing and agricultural sector has been ignored since an early time. Arts and cultural sector have been the sector that people worked on without thinking about income or any profit from it.

Assessment of the direct and indirect impacts of arts and culture industry through supply chains. Examinations of the multiplied impacts of this industry has shown that the contributions to macroeconomics indicated the gross value-added income to GDP, household incomes, employment rate growth. (Cebr, 2017)

As a result, there is an extreme need for this industry to have multiple researches and proposals in Sulaimani city, since it is claimed to be the capital city of culture in KRG (Kurdistan regional government). It is important to gain profits from this industry rather than focusing on oil or other sectors. This research is a beginning to find out the interest ranges and the quality of the arts and cultural industry in Sulaimani region. 
So as a conclusion, a city to be a capital should acquire all the four bourdieu of capital principles. A city should have (Economic capital, cultural capital, symbolic capital and social capital). Sulaimaniyah doesn't have economical capital for sure, while it has cultural, symbolic and social capital. In this research I am aiming to focus on the economic capital growth using creative sectors as Sulaimaniyah has the potential to be a creative city along with having all the other three capitals.

In Britain after 1980s, activities in arts and culture have become very important in advancing the economy of the country.

The importance's been realized from early times in so many countries. As Pratt, 1997 says. "Much attention has been paid to developing analyses of the indirect impact of the arts and cultural industries. Urban managers in the US and latterly the UK have developed economic impact studies that have sought to explore the extra economic activity generated by arts and culture; predominantly via participation figures, and secondary impacts via proximity on shopping and tourism, as well as transport and accommodation. Such studies have effectively re-legitimized arts investment (that is not-for-profit art activity) within a new state regime." (Pratt, 1997)

\section{Methodology and Results}

1. Secondary data were obtained from 'Sulaimaniyah Chamber of Commerce and Industry". The data shows all companies in Sulaimaniyah that has been registered to get accreditation. And we classified the companies and firms that work in creative sectors. Such as film production, sewing, music production, IT, design and printing, publishing, and advertising.

2. Interviews are made with several successful business owners that work in creative sectors. The purpose is to know their progress, perception and challenges. Interviews are yet to be finished.

Hama group is one of the earliest and most experienced advertising agencies in the KRG. It is composed of three major departments: production house, a creative agency, and a media buying agency. Hama group's HR manager (Rezan Ismail) explained that the company has a positive progress in 10 years. She said that it started with one camera and now they have projects continuously and more than 60 employees. They are focusing on future plans to work internationally.

Hawar Muhammad Sdiq (Designer) said that she is working on the culture of Kurdistan and gets her inspiration from Kurdish culture. H\&L Designs is the only Kurdish clothes design brand that has only 3 staff, a mother and two daughters. They also work internationally, and they work with famous Kurdish people. Culture factory is a new project in Sulaimaniyah. It is supporting the idea of creative city to be worked on in sulaimaniyah. The transformation of cigarettes factory to cultural factory is a big movement for Sulaymaniyah. 
Figure 1 Registered Companies in Sulaymaniyah (Source: Commercial Union of Sulaymaniyah)

\section{All registered companies in Sulaimaniyah Province} creative Companies, $253,5 \%$

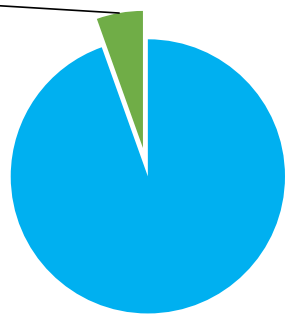

other companies, $4,382,95 \%$

- other companies creative Companies

The year 1985 was the year data collecting of chamber of commerce started. And since then, every year an average of 4 companies working in creative sector was established. The rise of revolution in Kurdistan saw these figures drop to 0 . Until the year 2003 and the Iraqi liberations process.

The data shows in above pie chart that Sulaimaniyah has 4,382 registered companies but only 253 companies that are registered are working in the "creative sector".

Figure 2 Registered Creative Sector Companies According to Year (Source: Commercial Union of Sulaymaniyah)

\section{Creative Companies Established in Sulaimaniyah (1985-2018)}

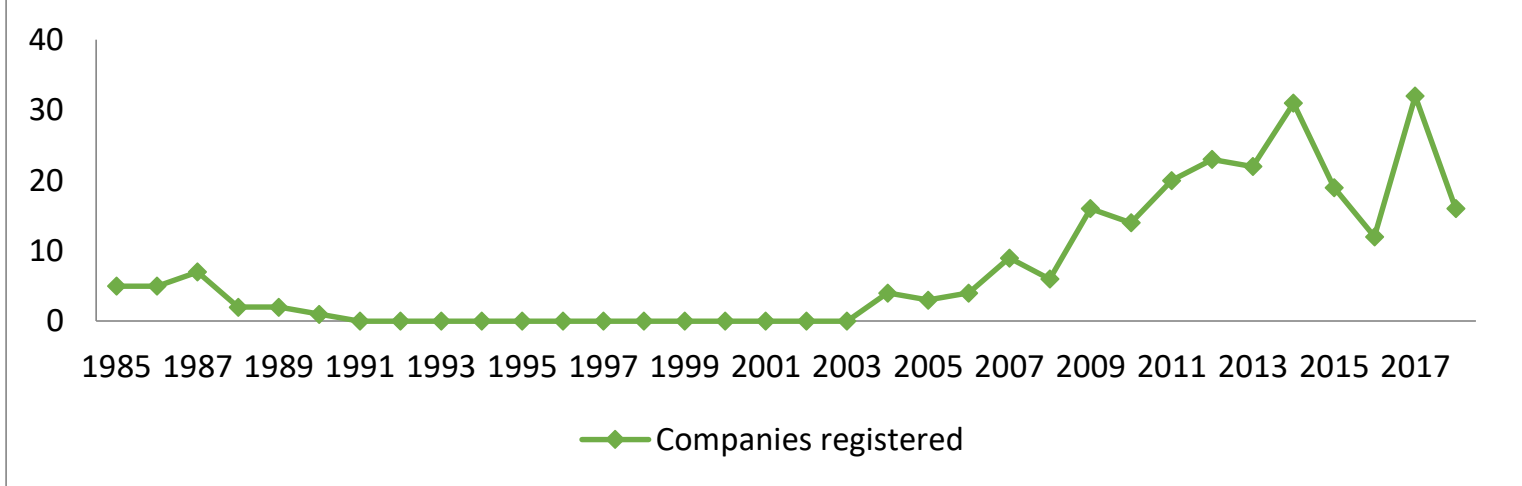

The number of companies established each year was affected by the events and incidents that happened in the country. Iraq-Kurdistan war in 1990. Saddam has attacked Kurds in a massive way and Kurdish people left their country. 1991 Kurdish Uprising. The decision of IKP 
to announce Sulaimaniyah as the capital of culture initiated a visible increase in the establishment of creative companies in 2012. In the years of 2014, the war of ISIS caused these numbers to fall.

\section{Conclusion}

It is shown from the figure $A$ that the number of registered companies in Sulaimaniyah city are approximately 5,000 companies which is not considered as a small number compare to the geographical size of the city and total population. However, the number of companies which is considered as creative companies are not large compare to the total companies which is registered in the city. The total creative companies are just approximately 300 companies and most of these companies are service companies like companies related to technology, IT and web design and trading some equipment related to technology.

The main arguments why the contribution of creative companies to total companies is not high is related to the rentier states. Iraq economy depends mainly on oil in terms of government revenue and contribution oil sector to total GDP.

Based on economy theories and most of empirical studies in oil exporting developing countries, when the oil revenue increases, the construction and service sector will develop faster than other economic sector such as manufacturing and agriculture sector.

Among manufacturing sector there are plenty of branches which are considered as a creative sector. However, the manufacturing sector does not improve in oil exporting developing nations due to Dutch disease, then the creative companies does not encourage to increase and develop in oil economies. However, some types of service sector can be improved due to increase oil revenue.

As can be seen from the figure that there are number of creative companies that have been improved and enlarged when oil revenue increases from 2003 to 2013. It can be summarized that the number of creative companies are not many in terms of number, while it is considered that few of them are developed particularly during high oil revenue.

Sulaimaniyah has many creative people, many heritage sites and many opportunities to develop the city in ways of economics and culture. there are only a few of people that work on this issue such as Sherwan Ali Hama Khan. He is the first one in sulaimaniyah that made research about the effect of culture and that he suggested cigarettes factory to be restored and to transform it to a culture factory.

Also, culture factory is a movement and example for Sulaimaniyah to transform its heritage places into museums, galleries, music studios, design and printing houses, theatre halls, and radio stations, architecture, film productions, magazines, programming and IT.

It is suggested that the government should support and consider creative sectors. Old buildings or heritage sites shouldn't be destroyed for cars to be parked on. The symbolic places should be restored. Cultural activities should be increased so that the local people become tourists for their own city and that will affect the income of the city in term of creative economy.

Through creative arts and cultural activities, people get educated by interacting with any work made for the purpose of expression. Creativity which is an aspect of culture, existed since the moment human beings started dwelling in this earth.

This research focused on the importance of creativity and it supports creative sector to get improved by the creative people. Research gap and data gap effects every aspect of 
evaluating creative sectors. But. It is a positive sign that the data of creative sector companies exist. Although, a small number of companies are working on creative sectors. But few companies are better than not having any company at all. Also, the success of several business owners is significantly affecting Sulaymaniyah's economics. The designer said that their business was the reason for accessory markets to get demands. The focus of this research was to identify the problem and the reason of the city's creative sectors. Politics of Kurdistan Region of Iraq is not stable and has many conflicts. Thus, it affects creativity and cultural activities and events in a negative way. Since political issues or wars psychologically raises fear and makes people to be insecure and when a human being is afraid of something, he/she can't be creative.

Creativity have the quality to reach out for more than facts. It is the imagination of beings, the evaluation and expression of human consciousness and subconsciousness. As a result, there is an extreme need for creative sectors to have multiple researches and proposals in Sulaimani city, since it is claimed to be the capital city of culture in KRG (Kurdistan regional government). It is important to gain profits from creative economy rather than focusing on oil or other sectors. This research is a beginning to find out the interest ranges and the quality of the creative sectors and cultural industry in Sulaimani region.

To put in a nutshell, Sulaimaniyah has the capacity, the potential to become a creative city and hence be economically independent on mere oil and energy industry. The creativity potential of the city can merge with the new techniques to make the city a complete capital by having all the four principles of capital.

Based on the data collected it is clear that the potential is available to turn the city into a creative city. And as speculations from the data predict, the current economic recourses are already about to run out. And it is likely that we must turn to creativity instead of tools and instruments.

There are several ways to make the city a creative city. And I believe one of the best ways is for the authorities to create chances and open them up to opportunities. So, it becomes easier to practice creativity. Clearly the creative sectors are not all creative members of the community. There are a bigger number of creative members that are not able to engage with the sectors. There are several regulations for one to make a company (creative or not creative). So if the regulations are made easier for the creative sectors, if for instance the amount of money that needs to be paid to make a company made less to the creative sectors, a huge gate could be open for the creative individuals to practice their creativity into actions and make the dream a reality.

In addition to that, there needs to be creative activities in the city daily. So that the economy of the city becomes more active and locals will be tourists in their own city. Being constantly engaged with creative activities makes the community more open to future opportunities.

\section{References}

Landry, C. (2012). The creative city: A toolkit for urban innovators. Routledge.

Ali Hama khan, SH. (2019). The effect of transforming cigarettes factory in sulaimaniyah to culture factor.

Radich, A. J. (1992). Twenty Years of Economic Impact Studies of the Arts: A Review.

Omuaru, C. G., \& Nyah, A. A. (2015). Impact of Arts on Economic Development: The Nigeria Experience. Annals of Humanities and Development Studies, 6(1), 117-129. 
Bryan, J., Hill, S., Munday, M., \& Roberts, A. (2000). Assessing the role of the arts and cultural industries in a local economy. Environment and planning $A, 32(8)$.

Seaman, B. A. (2009). Cultural economics: The state of the art and perspectives. Estudios de Economía Aplicada, 27(1), 7-32.

McMillen, S., Helming, T., Qaiser, S., Sheridan, M., Finkle, V., \& Saha, M. (2006). The Economic Impact of the Arts, Film, History and Tourism Industries in Connecticut (No. 2006-Dec01). University of Connecticut, Connecticut Center for Economic Analysis.

Richards, G., \& Wilson, J. (2004). The impact of cultural events on city image: Rotterdam, cultural capital of Europe 2001. Urban studies, 41(10), 1931-1951.

Madden, C. (2001). Using 'economic'impact studies in arts and cultural advocacy: A cautionary note. Media International Australia Incorporating Culture and Policy, 98(1), 161-178.

Faulkner, S. (1999). A cultural economy of British art: 1958-1966 (Doctoral dissertation, Manchester Metropolitan University).

Towse, R. (Ed.). (2011). A handbook of cultural economics. Edward Elgar Publishing.

Waits, M. J. (2014). Five roles for arts, culture, and design in economic development. Community Development Investment Review, (02), 017-023.

Reeves, M. (2002). Measuring the economic and social impact of the arts: a review. London: Arts Council of England.

Bennett, T., \& Silva, E. (2011). Introduction: Cultural capital-Histories, limits, prospects. Poetics, 39(6), 427-443.

Borg, V. D. J., \& Russo, A. P. (2005). The impacts of culture on the economic development of cities. Rotterdam: European Institute for Comparative Urban Research.

Report for Arts Council. (2017). Contribution of the arts and culture industry to the UK economy an updated assessment of the macroeconomic contributions of the arts and culture industry to the national and regional economies of the UK. Cebr: London, UK 